\title{
Variability Analysis in Cassava (Manihot esculenta Crantz) under Coastal Salinity Conditions of Karaikal, India
}

\author{
Jibna Annie George* and V. Kanthaswamy
}

Department of Horticulture, Pandit Jawaharlal Nehru College of Agriculture and Research Institute, Tamil Nadu Agricultural University, Karaikal-609603, Puducherry, India

*Corresponding author

\begin{abstract}
A B S T R A C T
\section{Keywords}

Cassava, GCV, PCV, Heritability

Article Info

Accepted:

12 March 2019

Available Online:

10 April 2019

The 33 diverse genotypes were evaluated for mean performance, genetic variability, heritability and genetic advance for yield and yield contributing characters namely plant height, number of leaves plant ${ }^{-1}$, length of the petiole, internodal length, number of tubers plant $^{-1}$, individual tuber weight, dry matter content of the tubers, tuber length, tuber girth, tuber length diameter ratio, harvest index, leaf area, starch, HCN content, tuber yield plant $^{-1}$. Analysis of variance revealed the presence of significant differences among the genotypes for all the characters. High estimates of genetic coefficient of variation for all characters except harvest index, indicating that the major part of variability was due to genetic constitution. Heritability in general was high for all the characters. The genotype CO 3 was identified as the best for tuber yield plant $^{-1}\left(2.48 \mathrm{~kg} \mathrm{plant}^{-1}\right)$ among the 33 genotypes.
\end{abstract}

\section{Introduction}

Cassava (Manihot esculenta Crantz) or tapioca which belongs to the family Euphorbiaceace is a diploid $(2 n=36)$.

High degree of variability exists among the genotypes for earliness, tuber yield, harvest index, dry matter content, branching habit, leaf area, starch, $\mathrm{HCN}$ etc.

Globally cassava is grown in an area of 18.57 million ha producing 230.27 million tonnes with 12.4 t. ha $^{-1}$ of productivity (Kanagarasu et al., 2014). The edible root supply energy for for more than 500 million people world-wide (Ceballos et al., 2006).

The present study was undertaken to find out genetic variability among the different characters studied.

\section{Materials and Methods}

The present investigation was conducted in the Department of Horticulture, Pandit Jawaharlal Nehru college of Agriculture and Research institute, Karaikal. Totally 33 genotypes were collected from different geographical location and utilized for study. 
Among 33 genotypes, 22 genotypes were collected from CTCRI, Thiruvanthapuram, seven varieties from different district of Kerala and four varieties from different district of Tamil Nadu were collected for the study.

The experiment was laid out in a Randomized Block Design (RBD) with two replications. The main field was ploughed thoroughly and the stem cuttings were planted in the ridge and furrows of $75 \mathrm{~cm}$ width at a spacing of 75 $\mathrm{cm}$. The cultural operations and plant protection measures were followed as per the package of practices recommended for cassava (CTCRI, Thiruvanthapuram)

The observations of five randomly selected plants were recorded. Observation was taken for yield and yield contributing characters.
The characters were namely plant height, number of leaves plant ${ }^{-1}$, length of the petiole, internodal length, number of tubers per plant, individual tuber weight, dry matter content of the tubers, tuber length, tuber girth, tuber length diameter ratio, harvest index, leaf area, starch, HCN content, tuber yield plant ${ }^{-1}$. The recorded data was subjected to statistical analysis and means were compared by DMRT (Duncan Multiple Test Range)

\section{Results and Discussion}

The analysis of variance exhibited significant difference among the genotypes for all the characters. The phenotypic variance was higher than the genotypic variance for all the characters under study. Among the 15 characters studied the genotypic variance was high for plant height in the present study.

Table.1 Estimation of variability parameters for cassava genotypes

\begin{tabular}{|c|c|c|c|c|c|c|c|c|}
\hline \multirow{2}{*}{$\begin{array}{l}\text { S. } \\
\text { No }\end{array}$} & \multirow[t]{2}{*}{ Characters } & \multirow[t]{2}{*}{ Range } & \multirow[t]{2}{*}{ Mean } & \multicolumn{2}{|c|}{ Coefficient of variance } & \multirow{2}{*}{$\begin{array}{c}\text { Heritabi } \\
\text { lity } \\
\left(\mathrm{h}^{2}\right)\end{array}$} & \multirow{2}{*}{$\begin{array}{l}\text { Genetic } \\
\text { advance }\end{array}$} & \multirow{2}{*}{$\begin{array}{c}\mathrm{GA} \text { as } \\
\text { per cent } \\
\text { mean }\end{array}$} \\
\hline & & & & $\begin{array}{c}\mathrm{GCV} \\
\text { (per cent) }\end{array}$ & $\begin{array}{c}\text { PCV } \\
\text { (per cent) }\end{array}$ & & & \\
\hline 1 & Plant height $(\mathrm{cm})$ & $\begin{array}{l}120.80- \\
290.30\end{array}$ & 187.61 & 25.87 & 25.90 & 99.73 & 99.84 & 53.22 \\
\hline 2 & Numbers of leaves/plant & $45.00-213.50$ & 94.38 & 45.02 & 46.37 & 94.24 & 84.97 & 90.03 \\
\hline 3 & Length of the petiole $(\mathrm{cm})$ & $13.90-34.90$ & 22.95 & 22.44 & 22.61 & 98.48 & 10.52 & 45.87 \\
\hline 4 & Internodal length $(\mathrm{cm})$ & $1.46-4.30$ & 2.57 & 27.07 & 28.02 & 94.06 & 1.39 & 54.09 \\
\hline 5 & Number of tubers per plant & $4.80-15.00$ & 7.16 & 33.18 & 35.61 & 86.72 & 4.55 & 63.65 \\
\hline 6 & Individual tuber weight $(\mathrm{g})$ & $125.00-312.72$ & 211.13 & 24.55 & 24.73 & 98.48 & 105.94 & 50.18 \\
\hline 7 & $\begin{array}{l}\text { Dry matter content of tubers (per } \\
\text { cent) }\end{array}$ & $16.45-46.14$ & 34.71 & 18.05 & 18.20 & 98.27 & 12.79 & 36.86 \\
\hline 8 & Tuber length $(\mathrm{cm})$ & $13.40-32.14$ & 16.45 & 23.50 & 23.74 & 97.92 & 10.16 & 47.90 \\
\hline 9 & Tuber girth $(\mathrm{cm})$ & $12.85-25.51$ & 18.26 & 19.98 & 20.08 & 98.87 & 7.47 & 40.92 \\
\hline 10 & Length /diameter ratio of tuber & $2.65-5.26$ & 3.85 & 19.50 & 19.60 & 98.43 & 1.53 & 39.85 \\
\hline 11 & Harvest index (per cent) & $45.54-63.75$ & 55.98 & 7.41 & 7.77 & 90.98 & 8.15 & 14.56 \\
\hline 12 & Leaf area $\left(\mathrm{cm}^{2}\right)$ & $149.65-664.72$ & 285.08 & 43.00 & 43.02 & 99.88 & 252.37 & 88.53 \\
\hline 13 & Starch (per cent) & $25.40-40.00$ & 28.90 & 13.17 & 13.31 & 97.90 & 7.75 & 26.85 \\
\hline 14 & HCN Content (ppm) & $33.50-154.00$ & 64.33 & 47.63 & 47.66 & 99.87 & 63.09 & 98.06 \\
\hline 15 & Tuber Yeild/plant $\left(\mathrm{Kg}^{-1}\right)$ & $1.18-2.48$ & 1.82 & 16.80 & 17.80 & 90.61 & 0.60 & 32.94 \\
\hline
\end{tabular}

The genotypic coefficient of variance (GCV) and phenotypic coefficient of variation (PCV) was high for plant height, number of leaves plant $^{-1}$, length of the petiole, internodal length, number of tubers per plant, individual tuber weight, tuber length, tuber girth, leaf area and HCN content in this study (Table 1). Similar findings were also reported by Silpa 
(2015) in sweet potato. In the present study, the heritability values were high for all the 15 characters. High heritability also indicated that there was more number of additive factors for these characters. All the characters exhibited higher values of genetic advance as percent of mean except the harvest index (moderate GA percent mean), along with higher estimates of heritability. The results were conformity with the findings of Sankari et al., 2001 in sweet potato.

In conclusion, present investigation revealed that a few of the most promising genotypes for higher tuber yield based on mean performance were CO 3, Sree Rekha and Sree Prabha. The characters having high heritability coupled with high genetic advance over percent of mean in all characters except harvest index indicates that these characters are governed by additive gene action and will help the breeder to develop superior variety through simple selection procedure such as mass selection and recurrent selection.

\section{References}

Ceballos, H., T. Sáncheza, A.L. Chaveza, C. Iglesiasa, D. Deboucka, G. Maflaa and J. Tohmea. 2006. Variation in crude protein content in cassava (Manihot esculenta Crantz) roots 19(6): 589-593

Kanagarasu S., F. Justinraj, J. Prem, S. Ganeshram and A. Joel, 2014. Exploration and collection of cassava (Manihot esculenta Crantz) in Western Ghats and characterisation for industr use. Res. J. Recent. Sci. Vol. 3: 248-255.

Sankari, A., S. Thamburaj and M. Kannan. 2001. Genetic variability in sweet potato, J. Root Crops., 27 (1): 71-73

Silpa, R. 2015. Genetic evaluation of sweet potato (Ipomea batatas.L) varieties under coastal region of Karaikal. M.Sc (Hort.) Thesis, Tamil Nadu Agricultural University, Coimbatore.

\section{How to cite this article:}

Jibna Annie George and Kanthaswamy, V. 2019. Variability Analysis in Cassava (Manihot esculenta Crantz) under Coastal Salinity Conditions of Karaikal, India. Int.J.Curr.Microbiol.App.Sci. 8(04): 1436-1438. doi: https://doi.org/10.20546/ijcmas.2019.804.167 